\title{
26
}

\section{Case Law of the European Court of Human Rights on the Application of (Some of) the EU Family Regulations}

\author{
PATRICK KINSCH
}

\section{Introduction}

The European Court of Human Rights (ECtHR) has important tasks, but the authoritative construction of the European family regulations is not part of them. The ECtHR applies only one international instrument, the European Convention on Human Rights. Nonetheless, a presentation of its case law is of interest in the present context: while the ECtHR is not a specialist court in the area, some of its cases touch on the application of the EU family regulations and are authoritative as to the requirements of European human rights law in that field - as in innumerable others.

Of all the various regulations of the EU in the field of family law, only three have played a role, up to now, in the case law of the ECtHR. ${ }^{1} \mathrm{~A}$ few cases relate to the Maintenance Regulation, and the overwhelming majority of cases concern one specific (but important) issue under the Brussels II and Brussels IIa Regulations, namely international child abductions and the issuing and enforcement of orders for the return of children.

None of the remaining EU regulations in the field of international family law have had any importance before the ECtHR. Only for the sake of academic completeness: there is a fleeting reference to the provision on forum necessitatis (Article 11) of the Succession Regulation in the Grand Chamber judgment in Naït-Liman v Switzerland. But this appears only as a comparative reference in a section on 'European Union law', to which the Court 'consider[ed] it appropriate to refer.'2

\footnotetext{
${ }^{1}$ The case law of the ECtHR is available on its HUDOC database at hudoc.echr.coe.int/eng. This contains a full collection of the cases decided by the Court and by the former European Commission of Human Rights.

${ }^{2}$ Naït-Liman $v$ Switzerland App no 51357/07 (ECtHR, 15 March 2018) \$92. The case itself did not, of course, concern anything as mundane as the EU family regulations. It concerned torture in Tunisia, and the denial of a forum in Switzerland for a claim for damages against the Tunisian state and its former Minister of the Interior.
} 


\section{Two Cases Relating to the Maintenance Regulation}

The two cases which will be presented here concern the Maintenance Regulation only indirectly: in fact, both of them show that the Regulation, the procedures of which had not been used, would have allowed a more effective enforcement of maintenance obligations towards children. These cases can be cited, therefore, as indirect confirmation from the ECtHR that the Maintenance Regulation is in fact a useful mechanism for preventing violations of human rights.

\section{A. Battista $v$ Italy $^{3}$}

This was a case involving the refusal of a new passport to the applicant (a man residing in Naples), who had requested that the name of his son be added to it while the applicant and his wife were in judicial separation. The new passport was refused by the guardianship judge on the specific grounds that the applicant was not making the maintenance payments ordered by the president of the court at the time of the judicial separation. To make things worse, the Naples Police Commissioner (Questore di Napoli) ordered the applicant to surrender his passport, and amended his identity card, making it invalid for foreign travel. All appeals to Italian courts were to no avail: the actions by the Questore were far from arbitrary, since under an article of the Italian passport law, ${ }^{4}$ 'a passport may be withdrawn from a person who is abroad and is unable to prove that he or she has made maintenance payments as ordered by a court decision in respect of his or her minor children'.

Before the ECtHR, the applicant relied on an important human right, namely the freedom to leave any country, including one's own (Article 2 of Protocol No 4 to the Convention). Was the withdrawing of the applicant's passport, an indisputable interference with that right, justified by the need to protect his children? Was it necessary to ensure that the applicant made his maintenance payments, thus preventing the commission of an offence, namely violation of the obligations to assist one's family?

While the Court considered that the measures imposed on the applicant pursued a legitimate aim, namely the protection of the rights of others - in the present case, the children's right to receive the maintenance payments - it was held that it did so in a wholly disproportionate manner, thus violating the right to freedom of movement. The Italian authorities had not 'consider[ed] it necessary to examine the applicant's personal situation or his ability to pay the amounts due, and applied the impugned measure automatically', and they had not sought to balance the applicant's rights with those of his children. ${ }^{5}$ Above all, misuse of his passport by the applicant to abscond to

\footnotetext{
${ }^{3}$ Battista $v$ Italy App no 43978/09 (ECtHR, 2 December 2014).

${ }^{4}$ Section 12 of Law No 1185 of 21 November 1967 as amended by the Passports Act 2003 (Law No 3).

${ }^{5} \S 44$.
} 
another country would not have been successful, at least not if in the new country of residence, an efficient instrument for the recovery of maintenance payments, such as the Maintenance Regulation, were in place:

the Court notes that there has been civil-law cooperation at European and international level on the issue of the recovery of maintenance payments. It points out that there exist methods for obtaining recovery of debts outside national boundaries, in particular Council Regulation (EC) no. 4/2009 of 18 December 2008 on jurisdiction, applicable law, recognition and enforcement of decisions and cooperation in matters relating to maintenance obligations, the Hague Convention of 23 November 2007 on the International Recovery of Child Support and Other Forms of Family Maintenance, and the New York Convention on the Recovery Abroad of Maintenance. Those instruments were not taken into account by the authorities when applying the impugned measure. They had merely emphasised that the applicant could have travelled abroad using his passport and thus succeeded in evading his obligation. ${ }^{6}$

\section{B. Orel v Croatia ${ }^{7}$}

Mrs Orel and her two children sought to enforce a judgment for maintenance rendered by a Croatian court against the father of the children, who had emigrated to the United States. Having been unsuccessful, they turned to the ECtHR and brought an application against Croatia for failure to comply with its 'positive obligation' to assist the applicants in enforcing the judgment abroad. Such a positive obligation is considered in the Court's case law as resulting from the right to effective enforcement of a judgment given by a national court, a corollary of the right to a fair trial. ${ }^{8}$

It was held by the Court, which rejected the application as manifestly unfounded, that the Croatian authorities could not be blamed for unenforceability of the maintenance judgment in the United States. Croatia had a network of international enforcement mechanisms in place, including the Maintenance Regulation. The problem was that none of these applied to the United States, a state that (unlike Croatia) was not a party to the United Nations Convention on the Recovery Abroad of Maintenance of 1956. And the United States is not bound by the Maintenance Regulation to which the decision of the Court expressly refers. ${ }^{9}$

\footnotetext{
${ }^{6} \$ 45$.

${ }^{7}$ Orel $v$ Croatia App no 51506/13 (ECtHR, 7 June 2016).

${ }^{8}$ That specific use of the positive obligations of states in the context of international enforcement of judgments is not illogical (indeed, it is rather unproblematic to consider that the guarantee of a fair trial entails a right to effective enforcement of judgments rendered in a Contracting State such as Croatia, and that if enforcement is only possible in a non-Contracting State such as the United States, the Croatian authorities have some kind of positive obligation to assist those having obtained a judgment in Croatia to enforce it abroad). But in general, it will be against the recognising (or, in some cases, non-recognising) state that the proceedings will be brought: for a discussion of the problematic aspects thereof, see P Kinsch, 'Enforcement as a Fundamental Right' (2014) NIPR 540.

${ }^{9}$ At $\$ 46$ of the decision, in the preliminary section on 'Relevant international and European law'.
} 


\section{Child Abduction Cases under the Brussels II and Brussels IIa Regulations and under the European Convention on Human Rights}

The cases dealing with the human rights aspects of international child abductions have become so numerous that they have become a well-defined, distinct area of activity of the ECtHR. Contrary to other types of cases (in particular, cases on choice-of-law problems, which are few and far between), ${ }^{10}$ they have become part of the routine work of the Court, whose jurisprudence in the area of child abductions has frequently been studied. ${ }^{11}$ It would not seem worthwhile to repeat the content of those studies and to present again all of the Court's cases. Instead, we will concentrate on two points. First, the relevant Article of the Convention, Article 8 and its guarantee of the right to enjoy family life, creates an obligation for states to strike a balance between two aspects of family life, which are not easily reconciled in the case of child abduction. Second, several provisions of the Brussels IIa Regulation make it difficult to maintain that balance required by the Convention and therefore create the potential for a conflict between EU law and European Human Rights Law.

\section{A. The Two Faces of Article 8 of the Convention}

Under Article 8 of the Convention, 'everyone has the right to respect for ... his family life. What this right means in the context of international child abductions had been defined first (before the cases regarding the application of the Brussels II and Brussels IIa Regulations started coming in) by reference to the functioning and sometimes the malfunctioning of the 1980 Hague Child Abduction Convention. In numerous cases concerning orders for the return of abducted children to their former place of habitual residence, the most prominent of which are Maumousseau and Washington $v$ France, ${ }^{12}$ Neulinger and Shuruk $v$ Switzerland, ${ }^{13}$ and $X v$ Latvia, ${ }^{14}$ the Court insisted that there was a need for a 'fair balance' to be struck between various interests: those of the child, those of the mother, those of the father, and society's interest in public order (and in

\footnotetext{
${ }^{10}$ The most remarkable case on choice of law - not involving any of the European regulations - of the last years was Harroudj $v$ France App no 43631/09 (ECtHR, 4 October 2012), involving the question of discrimination by a choice of law rule in the context of applying a child's national law to a request for its adoption. See also, in the related area of the recognition or non-recognition of foreign surrogacy arrangements, the cases of Mennesson v France App no 65192/11 (ECtHR, 26 June 2014), Labassee v France App no 65941/11 (ECtHR, 26 June 2014) and Foulon and Bouvet $v$ France App nos 9063/14 and 10410/14 (ECtHR, 21 July 2016), which go into the issue of the compatibility with the Convention of various private international law techniques, namely public policy and (in Foulon and Bouvet) fraus legis.

${ }^{11}$ See in particular ch 13, 'Right to Respect for Family Life and the Rights of the Child: International Child Abductions' in J Fawcett, M Ní Shúilleabháin and S Shah (eds), Human Rights and Private International Law (Oxford, OUP, 2016), which gives a complete overview of the cases and those studies of them that have been published in English.

${ }^{12}$ Maumousseau and Washington v France App no 39388/05 (ECtHR, 6 December 2007), $\$ 62$.

${ }^{13}$ Neulinger and Shuruk $v$ Switzerland App no 41615/07 (ECtHR, 6 July 2010), \$ 134.

${ }^{14} X v$ Latvia App no 27853/09 (ECtHR, 26 November 2013), $\$ 95$.
} 
respect for judicial decisions ordering the return of the children). That line of cases was then extended, in the Court's jurisprudence, to cases involving the EU Regulations. ${ }^{15}$ Here is a quotation to that effect from a recent case involving the Brussels IIa Regulation:

In relations between EU Member States the rules on child abduction contained in the Brussels II[bis] Regulation supplement those already laid down in the Hague Convention. Both instruments associate the best interests of the child with restoration of the status quo by means of a decision ordering the child's immediate return to his or her country of habitual residence in the event of unlawful abduction, while taking account of the fact that nonreturn may sometimes prove justified for objective reasons that correspond to the child's best interests, thus explaining the existence of exceptions, specifically in the event of a grave risk that the child's return would expose him or her to physical or psychological harm or otherwise place him or her in an intolerable situation in accordance with Article 13(b) of the Hague Convention ... This task falls in the first instance to the national authorities of the requested State, which have, inter alia, the benefit of direct contact with the parties concerned. In fulfilling their task under Article 8, the domestic courts enjoy a margin of appreciation, which, however, remains subject to European supervision whereby the Court reviews under the Convention the decisions that those authorities have taken in the exercise of that power. ${ }^{16}$

In a child abduction case, by definition, the interests of the two parents are never in harmony. The typical case (judging from the ECtHR case law) has become one where the primary caregiver of the children, who is usually - 'usually' being understood, again, not in normative terms but in empirical terms based on the cases before the Court - the children's mother, takes advantage of the ease of international travel to 'leave with the children, usually to go back to her own family. ${ }^{17}$ In such cases the Convention's right to family life may, depending on the circumstances, be relied on by both parents to opposing ends. For instance, the father may claim his right to live with his children in the children's place of habitual residence before the abduction, while the mother exercises her right to freedom of movement (abducting the children in the process) and wishes to continue living with the children in their new place of residence. The right to family life will, prima facie, apply in all these cases. If invoked by the 'other parent' against the abducting parent, it will take the form of positive obligations of states under the Convention to enforce an order from a foreign jurisdiction for the children's return. If invoked by the abducting parent, the same right to family life works potentially as

\footnotetext{
${ }^{15}$ Such cases have by now become numerous. The most famous of them, to which we shall return later, is the Alpago/Povse case, brought first before the ECJ, judgment of 1 July 2010 in Case C-211/10 PPU Doris Povse v Mauro Alpago [2010] ECR I-6673, ECLI:EU:C:2010:400, then before the ECtHR by the mother, Sofia Povse and Doris Povse v Austria App no 3890/11 (ECtHR, 18 June 2013) held that Austria had not violated the applicants' right to family life by eventually ordering the enforcement of an Italian order for the return of the child to Italy, and finally, before the ECtHR as well, by the father, MA v Austria App no 4097/13 (ECtHR, 15 January 2015) held that there had been a violation of the father's right to efficient enforcement of the return of the child to Italy. On that case, see also below, section B.ii.

${ }^{16}$ Judgment Sévère v Austria App no 53661/15 (ECtHR, 21 September 2017), $\$ 100$.

${ }^{17}$ See the British case Re E (Children) [2011] UKSC 27 para 6. This opinion explains the change that has taken place in the paradigmatic situation in the field of international child abduction, from the case of a 'dissatisfied parent who did not have the primary care of the child snatching the child away from her primary carer', which the authors of the 1980 Hague Child Abduction originally had in mind, to a situation of the kind mentioned in the text.
} 
a protection against unjustified interference with existing family life, both against the unjustified entering of a return order ${ }^{18}$ and against its enforcement abroad. ${ }^{19}$

Since the Convention potentially extends protection to the contradictory interests of both parents, it cannot do without a rule for resolving conflicting interests. Hence the need, proclaimed by the Court's case law, for Contracting States to strike 'a fair balance' between the interests of both parents, together with the interests of the children and of society as a whole. When seeking to strike this balance, states must take into account 'that the best interests of the child must be of primary consideration and that the objectives of prevention and immediate return correspond to a specific conception of "the best interests of the child"' ${ }^{20}$ Where the matter becomes truly difficult is where the abducting parent plausibly argues that the best interests of the child and the interest in enforcing an order for his or her return to the former habitual residence truly are at odds. In this instance, the ECtHR will give preference to the best interests of the child, in line with Article 3(1) of the United Nations Convention on the Rights of the Child. ${ }^{21}$ This treaty deals specifically with children's rights, according to which 'in all actions concerning children ... the best interests of the child shall be a primary consideration'.

In general, the Court's case law is based on the idea that the mechanism provided for by the 1980 Hague Child Abduction Convention or (by extension) by the EU Regulations for the swift return of children to their habitual residence 'correspond[s] to a specific conception of "the best interests of the child"';2 the case law is based on the Court's holdings that there is a positive obligation for states to enforce orders for the return of children. But that positive obligation does not correspond to a hard and fast rule. The reason for its existence remains the protection of the interests of an individual: the child. Its aim is not to promote the integration of the intra-EU area of security, freedom, and justice in civil matters or to uphold the principle of mutual trust between states: those are aims of the EU Regulations in the area, including the Brussels II and Brussels IIa Regulations, but they are not aims that the European Convention on Human Rights - a project of the Council of Europe, not of the EU - would specifically pursue. Indeed, the differences in the aims pursued may lead to a conflict.

\section{B. The Potential for a Conflict between EU Law and European Human Rights Law}

\section{i. The Areas of Friction}

As a consequence of the difference in the policies pursued, there remain potential areas of friction between Article 8 of the ECHR and a number of provisions of the Brussels IIa Regulation. In order to promote the integration of the EU, Articles 11(8),

\footnotetext{
${ }^{18}$ A situation illustrated by a case involving the Brussels IIa Regulation, Šneersone and Kampanella $v$ Italy App no 14737/09 (ECtHR, 12 July 2011).

${ }^{19}$ As illustrated, among others, in a Hague Convention context by the three cases cited above (nn 12 to 14) which concern the relations with non-European states, or in the Brussels IIa context by MAv Austria (n 15).

${ }^{20}$ See, eg, Xv Latvia (n 14) §95.

${ }^{21}$ Signed in New York on 20 November 1989, UNTS, vol 1577, 3.

22 Sévère v Austria (n 16) \$101.
} 
40 and 42 of that Regulation allow the courts of the Member State of the child's habitual residence to order the immediate return of the child, regardless of a prior judgment of non-return pursuant to the 1980 Hague Child Abduction Convention. The order benefits from automatic enforceability in the other Member States 'without the need for a declaration of enforceability and without any possibility of opposing its recognition' (Article 42(1)), on the European enforcement order model. ${ }^{23}$

In two respects, that model potentially conflicts with the model inherent in Article 8 of the Convention.

First, the Convention ultimately makes the best interests of the child prevail over the idea of enforcing orders issued in another state.

If the courts ordered the return of the child and clearly had it wrong in ordering the return, the ECtHR will come to the conclusion that the originating state has violated the right to family life. ${ }^{24}$ That is not, as such, incompatible with the Regulation, which does not say that the return of children must always be ordered; on the contrary, the Regulation provides for procedural safeguards against unwise orders for the return of children. ${ }^{25}$ The problem arises at the level of the automatic enforcement of a return order in another Member State. It has been held by the Court, in cases where it was not the Regulation but the Hague Convention that applied, that it resulted from the 'principles that have emerged from its case law on the issue of the international abduction of children' that:

[a] child's return cannot be ordered automatically or mechanically when the Hague Convention is applicable, as is indicated by the recognition in that instrument of a number of exceptions to the obligation to return the child (see in particular Articles 12, 13 and 20), based on considerations concerning the actual person of the child and its environment, thus showing that it is for the court hearing the case to adopt an in concreto approach to it. ${ }^{26}$

The question arises, then, whether that principle also applies in cases of application of the Regulation. Of course, the Regulation itself does not contain any 'exceptions to the obligation to return the child, quite on the contrary. But does the automatic enforceability of return orders not bring with it, precisely, the risk of a violation by the returning state?

Second, the ECJ has held in Doris Povse v Mauro Alpago, ${ }^{27}$ on the construction of the Brussels IIa Regulation, that:

enforcement of a certified judgment cannot be refused in the Member State of enforcement because, as a result of a subsequent change of circumstances, it might be seriously detrimental

\footnotetext{
${ }^{23}$ The European Enforcement Order Regulation was the first implementation, in civil matters, of the decision at the Tampere European Council of 15 and 16 October 1999 to gradually do away with the Exequatur procedure for judgments rendered within the Union.

${ }^{24}$ As happened in Šneersone and Kampanella $v$ Italy (n 18), where it was held that the decision of an Italian court, issued under Brussels IIa, to order the return of a child to Italy violated by itself the rights of the child and his mother.

${ }^{25}$ Art 40(2): such orders can be given 'only if: (a) the child was given an opportunity to be heard, unless a hearing was considered inappropriate having regard to his or her age or degree of maturity; (b) the parties were given an opportunity to be heard; and (c) the court has taken into account in issuing its judgment the reasons for and evidence underlying the order issued pursuant to Art 13 of the 1980 Hague Convention'.

${ }^{26} M R$ and LR $v$ Estonia App no 13420/12 (ECtHR, 15 May 2012) $\$ 37$ (vi).

${ }^{27}$ Case C-211/10 PPU, Doris Povse v Mauro Alpago (n 15).
} 
to the best interests of the child. Such a change must be pleaded before the court which has jurisdiction in the Member State of origin, which should also hear any application to suspend enforcement of its judgment.

In tension with this holding of the ECJ, the ECtHR has held, in construing the positive obligation deriving from Article 8 of the Convention to enforce return orders in conformity with the Brussels IIa Regulation, as follows:

In the light of the principles above, according to which the best interests of the children must still be of primary consideration ... the Court accepts that a change in the relevant circumstances may exceptionally justify the non-enforcement of a final return order. However, having regard to the State's positive obligations under Article 8 and the general requirement of respect for the rule of law, the Court must be satisfied that the change in circumstances was not brought about by the State's failure to take all measures that could reasonably be expected to facilitate the enforcement of the return order. ${ }^{28}$

Given that the same judgment of the Court says that the task to assess a change of circumstances 'falls in the first instance to the national authorities of the requested state, which have, inter alia, the benefit of direct contact with the parties concerned', ${ }^{29}$ the question is whether those same national authorities truly can rely on the construction of the Regulation given by the ECJ and, in the interests of mutual trust among Member States, abstain from exercising their own judgment on what is required by the interests of the child in view of a change of the relevant circumstances. This may be incompatible with their obligations under the ECHR.

\section{ii. Evolving Case Law on the Ways to Resolve the Potential Conflict between EU Law and the Law of the Convention}

The case of Povse $v$ Alpago arose out of the decision of the Austrian mother (Doris Povse) of a child, Sofia Povse, to separate from the father (Mauro Alpago). She left Vittorio Veneto where the couple had lived with the child and returned to Austria, taking the child with her. Since the mother was not legally entitled to decide alone to change the child's habitual residence, the situation amounted to a case of child abduction. The case was taken by the father to a court in Venice, which decided to issue a return order under Article 11(8) of the Brussels IIa Regulation. A court in Austria, requested to enforce this order, refused to do so because enforcing it would 'create a grave risk of psychological damage to the child'. An intermediary appeal court in Austria reversed that decision, and Ms Povse appealed to the Austrian Supreme Court, which sent a preliminary reference to the ECJ. The ECJ confirmed the principle that it was for the court having made the return order - not for the court requested to enforce it in another Member State - to assess whether there had been a fundamental change to the circumstances such that enforcement of the order 'might be seriously detrimental to the best interests of the child. ${ }^{30}$ Therefore, the Austrian courts had to defer to the judgment of the

\footnotetext{
${ }^{28}$ Sévère v Austria (n 16) $\$ 105$.

${ }^{29}$ See the quotation above (n 16).

${ }^{30}$ See the quotation from Case C-211/10 PPU Doris Povse v Mauro Alpago (n 27).
} 
courts of Italy. This decision is entirely in line with the ECJ's view of mutual trust among Member States, which it considers to be an overarching principle, and the concern for individual rights tends to take second place (certainly at the time the Povse $v$ Alpago case was decided).

Ms Povse applied to the ECtHR, relying on the type of reasoning that had often been successfully invoked in Hague Convention cases. She failed; the Court rejected her application as 'manifestly ill-founded. ${ }^{31}$ The reason was that her case fell under the Bosphorus presumption, ${ }^{32}$ which the Court had created in 2005 in order to avoid interfering in the EU project by creating human rights obstacles to the smooth functioning of European unification. It basically presumes that the processes of the EU are equivalent, in terms of protection of human rights, to the provisions of the Convention, even where they do not literally comply with them in every procedural detail. It was held that the Bosphorus presumption could be applied to the Povse case. Had this been a non-EU case (falling under the Hague Convention), the Austrian courts would have been required to assess for themselves whether the protection of the applicants' right to family life required taking account of changed circumstances when refusing to enforce the Italian return order. But this would have contravened the policy behind a regulation of the EU; and that changed everything:

the CJEU made it clear that within the framework of the Brussels II[bis] Regulation it was for the Italian courts to protect the fundamental rights of the parties involved. Consequently, the applicants' rights have to be asserted before the Italian courts.

The Court is therefore not convinced by the applicants' argument that to accept that the Austrian courts must enforce the return order of 23 November 2011 without any scrutiny as to its merits would deprive them of any protection of their Convention rights. On the contrary, it follows from the considerations set out above that it is open to the applicants to rely on their Convention rights before the Italian Courts ... Should any action before the Italian courts fail, the applicants would ultimately be in a position to lodge an application with the Court against Italy (see, for instance Šneersone and Kampanella $v$ Italy ... concerning complaints under Article 8 of the Convention in respect of a return order issued by the Italian courts under the Brussels II[bis] Regulation).

In sum, the Court cannot find any dysfunction in the control mechanisms for the observance of Convention rights. Consequently, the presumption that Austria, which did no more in the present case than fulfil its obligations as an EU Member State under the Brussels II[bis] Regulation, has complied with the Convention has not been rebutted. ${ }^{33}$

And the Court subsequently held, on an application brought against Austria by the father, that it was the father's rights under Article 8 that had been violated (by excessive delay in enforcing the return order under the Brussels IIa Regulation), not the mother's. ${ }^{34}$ The dual outcome of the Povse $v$ Alpago case is, for the time being, the only holding of

\footnotetext{
${ }^{31}$ This phrase is sometimes used very loosely in the Strasbourg jurisprudence; let us say that the Court considered the application to be ill-founded on the basis of its contemporaneous case law.

${ }^{32}$ After the case of Bosphorus Hava Yollar Turizm ve Ticaret Anonim Şirketi v Ireland App no 45036/98 (ECtHR, 30 June 2005).

${ }^{33}$ Decision, Sofia Povse and Doris Povse v Austria App no 3890/11 (ECtHR, 18 June 2013) \$\$ 85-87.

${ }^{34}$ Judgment, MA v Austria App no 4097/13 (ECtHR, 15 January 2015).
} 
the ECtHR on the specific issue of the potential conflict between Brussels IIa and the Convention. This holding is very reassuring from the EU point of view of the principle of mutual trust in the relationships between Member States of the Union.

But this is not been the end of the matter. Other developments in case law throw doubt on the solidity of Povse's simple solution for a difficult conflict.

It was possibly the adamant attitude of the ECJ in Opinion $2 / 13,{ }^{35}$ by which it refused to consider that the draft agreement for the accession of the EU to the ECHR - an agreement foreseen by the Lisbon Treaty ${ }^{36}$ - was compatible with the EU and FEU treaties, that caused the renewal of the frictions between states' obligations under EU law and the European law of human rights. The ECJ saw a number of compelling (at least in its own view) reasons for its negative opinion; all but one were procedural reasons, and one was a substantive reason. The Convention, by obliging its Contracting States to exercise a second look when enforcing public acts (such as judgments) from other Member States and to verify whether the Convention had been complied with in the state of origin, was not compatible with the principle of mutual trust, which was a principle of constitutional significance in the EU:

the principle of mutual trust between the Member States is of fundamental importance in EU law, given that it allows an area without internal borders to be created and maintained. That principle requires, particularly with regard to the area of freedom, security and justice, each of those States, save in exceptional circumstances, to consider all the other Member States to be complying with EU law and particularly with the fundamental rights recognised by EU law.

In so far as the ECHR would, in requiring the EU and the Member States to be considered Contracting Parties not only in their relations with Contracting Parties which are not Member States of the EU but also in their relations with each other, including where such relations are governed by EU law, require a Member State to check that another Member State has observed fundamental rights, even though EU law imposes an obligation of mutual trust between those Member States, accession is liable to upset the underlying balance of the EU and undermine the autonomy of EU law. ${ }^{37}$

In the field of enforcement of public acts in another Member State, the Opinion thus sees as normal, and well worth preserving, the provisions of secondary EU legislation which eliminate a public policy review in the requested Member State, in particular by reference to the European Convention on Human Rights. ${ }^{38}$ Those provisions exist in EU family law (Articles 11(8), 40 and 42 of the Brussels IIa Regulation), in some aspects

\footnotetext{
${ }^{35}$ Case Opinion 2/13 [2014] ECLI:EU:C:2014:2454.

${ }^{36}$ Art 6(2) of the European Union Treaty, as amended by the Lisbon Treaty, provides that 'the Union shall accede to the $[\mathrm{ECHR}]$. Such accession shall not affect the Union's competences as defined in the Treaties.'

${ }^{37}$ Paras 191 and 194.

${ }^{38}$ Some of the regulations in civil and commercial matters remain true to tradition and provide for such a public policy review (see in particular, with relation to the Brussels I system, Case C-7/98 Dieter Krombach $v$ André Bamberski [2000] ECR I-1935, ECLI:EU:C:2000:164, and other cases), but others do not. See also an extrajudicial speech by K Lenaerts, president of the ECJ, 'The Principle of Mutual Recognition in the Area of Freedom, Security and Justice' (4th annual Sir Jeremy Lever Lecture, Oxford, 30 January 2015), in particular at 28: 'Since the EU is governed by the principle of democracy, it is for the EU political process to draw the line between unity and diversity. As a court that upholds the rule of law, the ECJ may only ascertain that, when drawing that line, the EU political institutions have complied with primary EU law, notably with the Charter'.
} 
of judgment recognition in civil and commercial matters (the European Enforcement Order model), but also - and, in political terms, most importantly - in criminal matters (the European Arrest Warrant), and in matters of asylum through the Dublin Regulation. The Opinion allows for non-enforcement in 'exceptional circumstances', it is true; but that exception refers (in the light of the earlier case law to which reference is made in the Opinion) to 'systemic' failure to observe human rights in the Member State of origin. ${ }^{39}$ In other cases, the necessities - as perceived by the ECJ - of the principle of mutual trust, the EU equivalent of a constitutional 'full faith and credit' clause, prevail over individuals' human rights.

Opinion 2/13 was not well received in Strasbourg, ${ }^{40}$ nor could it have been well received. Through its insistence on the 'autonomy of EU law', it showed that EU law, as interpreted by the ECJ, rejected any kind of heteronomy, even a heteronomy based on the international law obligation to comply with the Convention as interpreted by the ECtHR. The ECtHR reacted to that attitude in the Grand Chamber judgment in Avotinšs $v$ Latvia. ${ }^{41}$ Although it concerned the implementation in Latvia of the Brussels I Regulation - which does allow for a public policy review of judgments from other EU Member States, including a review as to compliance with the Convention ${ }^{42}$ - the Avotinš case was used by the ECtHR to set limits, clearly intended to be of general application, to the compliance of Contracting States with the logic of 'mutual trust'. The judgment starts out by the Court reaffirming the continued vitality of the Bosphorus presumption, ${ }^{43}$ and by declaring itself

mindful of the importance of the mutual recognition mechanisms for the construction of the area of freedom, security and justice referred to in Article 67 of the TFEU, and of the mutual trust which they require ... The Court has repeatedly asserted its commitment to international and European cooperation. ${ }^{44}$

But in reality, the Court had come to bury unconditional compliance with 'mutual trust', not to praise it:

In the Bosphorus judgment the Court reiterated that the Convention is a 'constitutional instrument of European public order'... Accordingly, the Court must satisfy itself, where the conditions for application of the presumption of equivalent protection are met ... that the mutual recognition mechanisms do not leave any gap or particular situation which would render the protection of the human rights guaranteed by the Convention manifestly deficient. ${ }^{45}$

Thus, 'manifest deficiency' in the protection of human rights in the originating state is sufficient to cause a requested state to refuse to enforce a decision. The 'manifest

\footnotetext{
${ }^{39}$ See the asylum case in joined Cases C-411/10 and C-493/10 NS and Others [2011] ECR I-13905, ECLI:EU:C:2011:865, referred to in para 191 of Opinion 2/13.

${ }^{40}$ See the opening address by D Spielmann, president of the ECtHR, on the occasion of the opening of the judicial year 2015 www.echr.coe.int 4-5.

${ }^{41}$ Avotiņš v Latvia App no 17502/07 (ECtHR, 23 May 2016).

${ }^{42}$ See fn 38 .

${ }^{43} \S 115$.

${ }^{44} \$ 113$.

${ }^{45} \$ 116$
} 
deficiency' standard, contrary to the standard of systemic failure to observe human rights, includes manifest deficiencies in individual cases. This is clearly shown by the reference that the Court makes to one of its decisions in child abduction cases, $X v$ Latvia, a case under the Hague Convention: ${ }^{46}$

In doing so it takes into account, in a spirit of complementarity, the manner in which these mechanisms operate and in particular the aim of effectiveness which they pursue. Nevertheless, it must verify that the principle of mutual recognition is not applied automatically and mechanically (see, mutatis mutandis, $X v$ Latvia [GC], no. 27853/09, \$\$ 98 and 107, ECHR 2013) to the detriment of fundamental rights - which, the CJEU has also stressed, must be observed in this context. ${ }^{47}$

There follows a final appeal to civil disobedience by the courts of EU Members States where compliance with their obligations under EU would lead them to enforce decisions from other Member States, despite the presence of 'manifest deficiencies' of human rights protection in the procedure having led to the issuing of the decision:

In this spirit, where the courts of a State which is both a Contracting Party to the Convention and a Member State of the European Union are called upon to apply a mutual recognition mechanism established by EU law, they must give full effect to that mechanism where the protection of Convention rights cannot be considered manifestly deficient. However, if a serious and substantiated complaint is raised before them to the effect that the protection of a Convention right has been manifestly deficient and that this situation cannot be remedied by European Union law, they cannot refrain from examining that complaint on the sole ground that they are applying EU law. ${ }^{48}$

There is no doubt that the fundamental holding of the Grand Chamber judgment in the Avotiņš case also applies in Brussels IIa Regulation cases. The terms of the judgment are too general to allow any kind of distinguishing. Indeed, the holding in Avotinš was recently repeated, by way of a short obiter dictum, in a Brussels IIa case:

[U]nder Article $11 \S 8$ of the Brussels II bis Regulation, the State in which the child had its habitual residence prior to the wrongful removal can override a decision refusing to order that child's return, pursuant to Article 13 of the Hague Convention. If such a decision is accompanied by a certificate of enforceability, pursuant to Article 42 of the Regulation, the requested State has to enforce it. Under Article 47 of the Regulation, the law of the State of enforcement applies to any enforcement proceedings (see M.A. v. Austria, no. 4097/13, $\$ \$ 112$ and 114, 15 January 2015). As the Court has previously held, it must verify that the principle of mutual recognition is not applied automatically and mechanically (see Avotiņš v. Latvia [GC], no. 17502/07, \$ 116, ECHR 2016). ${ }^{49}$

\footnotetext{
${ }^{46}$ See $\mathrm{n} 14$.

$47 \$ 116$.

${ }^{48} \mathrm{ibid}$.

${ }^{49}$ Royer v Hungary App no 9114/16 (ECtHR, 6 March 2018) $\$ 50$. The holding in Avotinš has also been applied in the matter of a European Arrest Warrant, which functions according to the same logic as enforcement orders in child abduction cases: Pirozzi v Belgium App no 21055/11 (ECtHR, 17 April 2018). The 'manifest deficiency' standard appears in that case as well ( $\$ \$ 3$ and 64, repeating the holding in $\$ 116$ of Avotiņš, and $₫ 71$ ), sometimes under the guise of the 'flagrant denial of justice' standard, well known in matters of international judicial assistance in criminal matters: $\$ \$ 57$ and 71 .
} 
Avotinšs should therefore be considered as partially overruling Povse v Austria in situations where the assessment of the child's best interests, or the incidence of a change of circumstances, in the originating court was 'manifestly deficient' from a human rights viewpoint. In those cases the courts in the Member State of enforcement are supposed to refuse to comply with the Regulation.

The question that remains - but it is a question for the ECJ - is whether it is desirable to continue to insist on strict compliance with those provisions of secondary EU law that purport absolutely to forbid the exercise of a 'second look' in the interest of protection of individual human rights. There are reasons to doubt it.

First and foremost, if the ECJ does not moderate its reading of the obligations of Member States, a moment will come where a true conflict between the obligations of a state as a Member State and its obligations as a Contracting State to the ECHR will appear. Then, the courts of that state - not the ECJ, nor the ECtHR - must take a final decision on the international, or supranational, obligations with which it will comply, and those that will be sacrificed. That is a paradoxical, indeed a disorderly, result, but one that will become inevitable. It would be preferable if it could be avoided.

Second, no one is presently asking the ECJ to abandon the idea of mutual trust as such. The ECtHR is prepared to adopt a compromise solution, as announced in Avotinš, and to allow states to comply with the logic of EU secondary law as long as compliance with that logic does not require them to tolerate 'manifest deficiencies' in the protection of human rights. Could this be a compromise solution for the ECJ as well, which could take the exception relating to 'systemic' failure to protect human rights a step further and individualise the exception? There have already been cases in the ECJ, on criminal law and on asylum law, which have accepted that states may take a 'second look' if the failure to do so might cause an individual to be subjected, in another Member State, to a violation of his or her right not to be subjected to inhuman or degrading treatment. ${ }^{50}$ Once that has been accepted, it would not appear excessive to expect the ECJ to accept a further exception for cases where the protection of other human rights has been 'manifestly deficient. ${ }^{51}$ Whether the ECJ will agree to do so remains to be seen - perhaps in a future case relating to international child abduction between Member States of the EU.

\footnotetext{
${ }^{50}$ See joined Cases C-404/15 and C-659/15 PPU Aranyosi and Căldăraru [2016] ECLI:EU:C:2016:198, paras 85 and 86 and Case C-578/16 PPU CK and Others v Republika Slovenija [2017] ECLI:EU:C:2017:127, para 75. Of course, given the ECJ's insistence on the 'autonomy of EU law', a violation of the right not to be subjected to inhuman or degrading treatment is no longer primarily treated, in judgments of the ECJ, as falling under Art 3 of the ECHR; it will be seen as a case under Art 4 of the EU Charter of Fundamental Rights. This is significant in terms of appearances, but probably not in terms of substance.

${ }^{51}$ In another extrajudicial contribution, K Lenaerts considers it possible that the EU may have to consider extending the exceptions to mutual trust in case of violations of fundamental rights other than the right not to be subjected to inhuman or degrading treatment: 'La vie après l'avis: Exploring the Principle of Mutual (Yet Not Blind) Trust' (2017) 54 CML Rev 805 at 835. And see D Spielmann and P Voyatzis, 'Létendue du contrôle du respect des droits fondamentaux à l'aune de l'expérience judiciaire comparée' [2017] RTDH 897 at 921.
} 
